March 2019

\title{
Dengue fever presenting as quadriparesis due to hypokalaemia: a rare presentation
}

Syed Muhammad Zubair

Aga Khan University

Syed Ahsan Ali

Aga Khan University, syed.ahsan@aku.edu

Saira Furqan

Aga Khan University, saira.furqan@aku.edu

Follow this and additional works at: https://ecommons.aku.edu/

pakistan_fhs_mc_med_intern_med

Part of the Infectious Disease Commons, and the Internal Medicine Commons

\section{Recommended Citation}

Zubair, S. M., Ali, S. A., Furqan, S. (2019). Dengue fever presenting as quadriparesis due to hypokalaemia: a rare presentation. Available at: https://ecommons.aku.edu/pakistan_fhs_mc_med_intern_med/130 


\title{
Dengue fever presenting as quadriparesis due to hypokalaemia: a rare presentation
}

\author{
Syed Muhammad Zubair, Syed Ahsan Ali, ${ }^{\odot}$ Saira Furqan
}

Medicine, Aga Khan University, Karachi, Pakistan

\section{Correspondence to \\ Dr Syed Ahsan Ali,}

syed.ahsan@aku.edu

Accepted 5 March 2019
Check for updates

(C) BMJ Publishing Group Limited 2019. No commercial re-use. See rights and permissions. Published by BMJ.

To cite: Zubair SM, Ali SA, Furqan S. BMJ Case Rep 2019;12:e227981.

doi: $10.1136 / \mathrm{bcr}-2018$

227981

\section{SUMMARY}

Dengue is one of the leading causes of arthropod borne viral haemorrhagic fever. Majority of the times, it clinically manifests as fever, arthralgia and rash; however, we present a case of a young man who presented with progressively increasing weakness of all four limbs. Initial investigations showed low potassium, hence he was managed as hypokalaemic periodic paralysis. With initial history of fever and low platelets, dengue was suspected. Dengue antibody was checked which came out to be positive. Potassium was replaced which led to improvement in power of his limbs. He was discharged in a stable condition with a diagnosis of dengue with hypokalaemic quadriparesis.

\section{BACKGROUND}

Dengue is one of the leading causes of arthropodborne viral haemorrhagic fever in tropical countries. As per WHO, it is the fastest-spreading vectorborne illness and is now endemic in over 100 countries. $^{1}$ Major clinical manifestations of dengue include fever, arthralgia, rash and petechiae. Although widely known as a non-neurotropic virus, certain neurological manifestations of dengue fever have been defined which include encephalopathy, seizures, stroke, acute pure motor weakness, mononeuropathies, polyneuropathies, Guillain-Barré syndrome (GBS) and transverse myelitis. $^{2}$ In 2009, WHO endorsed new guidelines that, for the first time, considered neurological manifestations in the clinical case classification for severe dengue. ${ }^{3}$ Here, we present a case of a young man, who has presented with acute quadriparesis due to hypokalaemia which has subsequently been diagnosed as dengue fever which is a rare presentation of dengue fever.

\section{CASE PRESENTATION}

A 33-year-old man presented to the emergency department with progressively increasing weakness of all four limbs which had started just 12 hours ago. He also reported fever 4 days previously which subsided a day ago. Weakness started from upper limbs and later progressed to involve lower limbs to an extent that patient was unable to move any of his limbs. There was no history of diarrhoea or ingestion of a heavy carbohydrate meal. There was no prior history of such limb weakness, and none of the family members of the patient had such symptoms. On arrival to the emergency department, he was vitally stable. On neurological examination, he had a power of $2 / 5$ in both upper limbs and $1 / 5$ in both lower limbs. He had brisk reflexes. His bladder and bowel functions were intact, and there was no sensory deficit at any level.

\section{INVESTIGATIONS}

Blood investigations were done which showed a haemoglobin of $16.2 \mathrm{~g} / \mathrm{L}$, total leucocyte count of $5.5 \times 10^{9} / \mathrm{L}$ with $89 \%$ polymorphs, $8.3 \%$ lymphocytes and $2 \%$ monocytes. Platelet counts were $136 \times 10^{9} /$ L. Blood biochemistry showed potassium of $1.9 \mathrm{mmol} / \mathrm{L}$, sodium of $136 \mathrm{mmol} / \mathrm{L}$, chloride of $103 \mathrm{mmol} / \mathrm{L}$, bicarbonate of $22.7 \mathrm{mmol} / \mathrm{L}$ and creatinine of $1.5 \mathrm{mg} / \mathrm{dL}$ which subsequently improved to $1 \mathrm{mg} / \mathrm{dL}$ on the following day. His liver function tests were done which showed normal serum bilirubin and transaminases. Serum alkaline phosphatase and gamma-glutamyl transferase were 184 $\mathrm{IU} / \mathrm{L}$ and $254 \mathrm{IU} / \mathrm{L}$, respectively. Malarial parasite was negative. Serum TSH (thyroid stimulating hormone) was $<0.004 \mu \mathrm{IU} / \mathrm{mL}(0.4-4.2 \mu \mathrm{IU} / \mathrm{mL})$, serum free T4 was $0.87 \mathrm{ng} / \mathrm{dL}(0.89-1.76 \mathrm{ng} / \mathrm{dL})$ and serum T3 was $1.22 \mathrm{nmol} / \mathrm{L}(1.08-3.14 \mathrm{nmol} / \mathrm{L})$. His platelet count on the following day was reported to be $66 \times 10^{9} / \mathrm{L}$ hence dengue IgM was checked which turned out positive and a diagnosis of dengue fever with hypokalaemic quadriparesis was established. Since patient's symptoms improved remarkably after potassium replacement, neuroimaging was not done to find out any neurological cause of weakness.

\section{DIFFERENTIAL DIAGNOSIS}

The differential diagnosis in this case can be GBS, hypokalaemic periodic paralysis and familial periodic paralysis. GBS was excluded on the basis of the fact that our patient had no history of diarrhoeal illness, reflexes were brisk on examination and showed immediate improvement on potassium replacement. There was no history of ingestion of carbohydrate meal which broadly excluded hypokalaemic periodic paralysis. And finally no family history of such weakness was given which excluded familial periodic paralysis. Although very low TSH points towards hypokalaemic periodic paralysis associated with hyperthyroidism, low normal free T4 and normal T3 excluded this diagnosis.

\section{TREATMENT}

Patient was treated with intravenous potassium chloride infusion. His serum potassium increased 
to $2.5 \mathrm{mmol} / \mathrm{L}$ initially and then to $5 \mathrm{mmol} / \mathrm{L}$, after which he regained motor power in his upper and lower limbs.

\section{OUTCOME AND FOLLOW-UP}

The patient was discharged on the 5 th day of admission in a stable condition with powers of $5 / 5$ in all four limbs.

\section{DISCUSSION}

Dengue is not widely known to present with neurological manifestations; however, rare instances have been defined which include encephalopathy, GBS, transverse myelitis, meningitis and acute pure motor weakness. Neeraja et al presented the unusual and rare manifestations of dengue fever in south India among which $7.4 \%$ cases were of dengue encephalitis. ${ }^{4}$ Kalita et al defined 16 cases presenting as acute pure motor quadriplegia due to myositis. ${ }^{5}$ Santos et al reported association of GBS and dengue fever. ${ }^{6}$ Jha and Ansari studied three confirmed dengue cases with pure motor reversible quadriparesis which showed remarkable improvement after potassium replacement. ${ }^{7}$ Gutch et al reported a similar case where a young male patient presented with quadriparesis due to hypokalaemia and was diagnosed with dengue fever as well. ${ }^{8}$ Roy et al reported two cases of patients presenting with dengue and hypokalaemic quadriparesis, both of whom showed remarkable improvement after potassium replacement. ${ }^{9}$ Our case was similar to those mentioned above in certain aspects as he showed the initial presentation of limb weakness after the resolution of fever, severe hypokalaemia and remarkable improvement in symptoms after potassium replacement.

The mechanism of hypokalaemia can be either due to renal tubular abnormalities or due to transcellular shift of potassium within cells. The incidence of dengue fever presenting as hypokalaemic quadriparesis is increasingly being reported. The association of dengue fever and hypokalaemia has been described in texts ${ }^{10}$ but not all of them lead to quadriparesis. Tomar et al proposed few other possible mechanisms of hypokalaemia in a patient with dengue which include redistribution of potassium in cells or transient renal tubular abnormalities leading to increased urinary potassium wasting, and increased catecholamine levels in response to stress due to infection may also result in hypokalaemia. Another possible mechanism for hypokalaemia is that endogenous granulocyte macrophage-colony stimulating factors, and related cytokines in response to neutropenia may lead to shift of potassium intracellularly. It is also possible that probably more than one mechanism may be responsible for the hypokalaemia in dengue infection. ${ }^{11}$

Assir et $a l^{12}$ reported expanded dengue syndrome which was associated with subacute thyroiditis and intracranial bleed. The patient had symptoms of hyperthyroidism with high free T3, T4 and low TSH. This is the first known case report of subacute thyroiditis associated with dengue which has been treated with steroids and propanolol. Our patient also had low TSH but free T4 was on slightly lower side. This can point towards a relation between viral illness and thyroid dysfunction; however, objective evidence is yet to be established. ${ }^{12}$

\section{Learning points}

In dengue endemic areas, dengue infection should be suspected in patients who present with quadriparesis and fever, so that early diagnosis and management can be facilitated.

- Limb weakness in a patient with dengue should be suspected as a manifestation of hypokalaemia rather than being a generalised fatigue caused by a viral illness. Therefore, potassium should be a part of initial investigations in patients presenting with dengue fever.

Contributors SMZ: conceived the idea, manuscript writing and literature review. SAA: reviewed and edited the manuscript. SF: reviewed and edited the manuscript.

Funding The authors have not declared a specific grant for this research from any funding agency in the public, commercial or not-for-profit sectors.

Competing interests None declared.

Patient consent for publication Obtained.

Provenance and peer review Not commissioned; externally peer reviewed.

\section{REFERENCES}

1 Dengue Control [Internet]. 2018 [cited 22 Aug 2018. http://www.who.int/ denguecontrol/human/en/

2 Li GH, Ning ZJ, Liu YM, et al. Neurological Manifestations of Dengue Infection. Front Cell Infect Microbiol 2017;7:449.

3 Carod-Artal FJ, Wichmann 0, Farrar J, et al. Neurological complications of dengue virus infection. Lancet Neurol 2013;12:906-19.

4 Neeraja M, lakshmi V, Teja VD, et al. Unusual and rare manifestations of dengue during a dengue outbreak in a tertiary care hospital in South India. Arch Virol 2014;159:1567-73.

5 Kalita J, Misra UK, Mahadevan A, et al. Acute pure motor quadriplegia: is it dengue myositis? Electromyogr Clin Neurophysiol 2005;45:357-61.

6 Santos NQ, Azoubel AC, Lopes AA, et al. Guillain-Barré syndrome in the course of dengue: case report. Arq Neuropsiquiatr 2004;62:144-6.

7 Jha S, Ansari MK. Dengue infection causing acute hypokalemic quadriparesis. Neurol India 2010;58:592-4.

8 Gutch M, Agarwal A, Amar A. Hypokalemic quadriparesis: An unusual manifestation of dengue fever. J Nat Sci Biol Med 2012;3:81-3.

9 Roy A, Tripathi AK, Verma SP, et al. Acute hypokalaemic quadriparesis in dengue fever. BMJ Case Rep 2011;2011:bcr1120103514.

10 Ying RS, Tang XP, Zhang FC, et al. [Clinical characteristics of the patients with dengue fever seen from 2002 to 2006 in Guangzhou]. Zhonghua Shi Yan He Lin Chuang Bing Du Xue Za Zhi 2007;21:123-5.

11 Tomar L, Raizada A, Yadav A, et al. Dengue fever presenting as hypokalemic muscle weakness. Tropical Journal of Medical Research 2016;19:76-8.

12 Assir MZ, Jawa A, Ahmed HI. Expanded dengue syndrome: subacute thyroiditis and intracerebral hemorrhage. BMC Infect Dis 2012;12:240

Copyright 2019 BMJ Publishing Group. All rights reserved. For permission to reuse any of this content visit

https://www.bmi.com/company/products-services/rights-and-licensing/permissions/

BMJ Case Report Fellows may re-use this article for personal use and teaching without any further permission.

Become a Fellow of BMJ Case Reports today and you can:

- Submit as many cases as you like

- Enjoy fast sympathetic peer review and rapid publication of accepted articles

- Access all the published articles

Re-use any of the published material for personal use and teaching without further permission

For information on Institutional Fellowships contact consortiasales@bmjgroup.com

Visit casereports.bmj.com for more articles like this and to become a Fellow 